\title{
コト・データベースによるモノ・コトづくり支援
}

\section{Product and Process Design Support based on 'COTO' Database}

\author{
渡辺 健太郎 \\ 独立行政法人産業技術総合研究所 サービス工学研究センター \\ Kentaro Watanabe \\ Center for Service Research, National Institute of Advanced Industrial Science and Technology \\ kentaro.watanabedaist.go.jp, http://unit.aist.go.jp/cfsr/
}

西村 拓一

(同上)

Takuichi Nishimura

本村 陽一

takuichi.nishimura@aist.go.jp

Yoichi Motomura

(同上)

持丸 正明

$y \cdot m o t o m u r a l a i s t . g o \cdot j p$

Masaaki Mochimaru m-mochimarueaist.go.jp

Keywords: COTO database, service design, service process patterns, technology map

\section{Summary}

The service industry takes a major role in the economic development. The enforcement of service activities in service fields is important for the further improvement of service productivity. For that purpose, it is effective to conduct the integrative development of service processes and support systems for them with the participation of stakeholders. Meanwhile, means to formalize and understand the current situations in service fields from multiple perspectives, such as how to collect data of service processes and how to analyze them have not been established yet. This causes the inefficiency of the development process. In this paper, the authors propose 'COTO' database to collect data on service processes with multiple perspectives in an integrative manner and how it works to support the design of service processes and systems by employees. In addition, the authors propose service process patterns and a technology map to choose an adequate models and technologies for COTO database in response to features of service processes. Finally, the authors discuss how the proposed methods are applied to service cases and the future prospect of this research scheme.

\section{1. はじめに}

今日，第 3 次産業は日本の GDP の 7 割弱を創出して おり, サービス分野の更なる生産性の向上は日本の産業 全体の発展に欠かせない. 顧客との接点であるサービス 現場の強化は，中でも重要な施策となる。主として人と 人の相互作用により価值創出を行う，人起点のサービス 現場の改善には，業務プロセス（コト）の正確な理解と 改良に加え，業務に用いる技術システム（モノ）の一体 的な開発が有効と考えられる。しかし，工場のようにラ インの稼働状況の把握や, 生産した製品の品質の定量的 な評価が比較的容易な環境と異なり, サービス現場では 各従業員がどのようなプロセスで, どのように連携して, 顧客に価值を提供しているかを正確に理解し, その上で 改善することは容易ではない.また，サービスの業務支 援を行う技術システムを開発するにあたり，現場の状況
を反映した要求仕様を決定することも容易ではない. 本課題に対し，現場関係者が主体的にコミュニティを 形成し, 外部専門家とともに業務プロセスの把握や改善, 技術システム開発を推進する現場参加型開発が注目され ている[西村 2013a]. このような開発アプローチの成功 例として，情報技術とコミュニティデザイン両方を把握 した人材を現場に送り, 新たな業務フローを構築しつつ, その業務フローに最適なシステムを開発するフィール ド・イノベーションというアプローチが挙げられる[有馬 2013].

その一方, サービス現場の特徵を把握するための視点 は多様に存在し，かつ現場毎に異なるため，業務プロセ スの形式化とその分析は未だ困難な状況にある.このた め, 過去の改善活動の成果を十分に記録・再活用できな い，あるいはシステム開発者等，コミュニティ外のメン バーとの知見の共有が十分にできない，等の状況が発生 
しやすい[Watanabe 2013]. また，得られた知見や開発さ れた技術も現場依存性が高く，同業他社，あるいは他業 態への水平展開が困難である.

そこで本稿では，業務プロセスの情報を多面的，かつ 選択的に蓄積・共有するコト・データベース (コト DB), 並びに，コト DB の情報を用いた，総合的なサービス現 場のモノ・コトづくり支援スキームを提案する。また， コト DB 化のアプローチとして，現場の業務プロセスの 特徴に合わせて，収集すべき情報や使用する技術を選択 するためのサービスの類型化と同類型に基づく技術選択 の方法論の提案を行う.

まず，次節では，人起点のサービス現場の特徵と現状 の課題について論ずる. 次に, 3 節にて, コト DB およ びその DB を活用したモノ・コトづくり支援スキームの 概要を示し，モノ・コトづくり支援に必要なコト DB 化 に有効な技術の選択方法論を提案する. 本方法論を構成 する要素として，4節ではコト DB 化におけるモデル ・ 技術選択に用いるサービスの業務プロセスの類型を提案 し，5節では，同類型に基づくコト DB 化技術マップを 提案すると共に, 関連事例の分析を行う. 6 節にて以上 の提案内容と関連事例に関する考察を行い, 7 節にて結 論と今後の展望を述べる.

\section{2. 人起点サービス現場の特徵と課題}

今日，多くのサービス現場では専門職化が進んでおり， 現場の包括的な理解が困難になっている，例えば医療現 場では，医師，看護師，薬剤師，事務スタッフ等，多職 種で構成されるが，その業務フローや役割分担は極めて 複雑化しており,さらに個々の従業員は多忙であるため, 相互の状況を把握することが難しい。 また，個々の従業 員の職種や特性により，業務上の関心や達成すべき目標 も異なる．このことが，時に相互理解や信頼関係の構築 も困難にし，ますます状況の正確な把握を難しくしてい る.

サービス現場における従業員の行動を理解する枠組 みとして, 西村らは従業員行動モデルを提案している[西 村 2013b]. 本モデルを図 1 に示す. 本モデルにおいて, 各従業員は，サービス提供を行う組織の果たすべきミッ ション, 並びに同ミッションから派生した個々の役割に 基づき, 業務を行う。一方, 個々の従業員の行動は, 組 織からトップダウン的に与えられたミッションや役割に よってのみ動機づけされるわけではなく, 従業員間の相 互理解に基づく共同意識や個々の主体性に依拠するとこ ろが大きい. 以上のような組織的・個人的動機づけに基 づき，従業員は業務を行っている.

現状, 動機づけ・意思決定過程も含め, 個々の従業員 の業務プロセスの多くが記録・共有されること無く消滅 している.このことが，従業員同士の相互理解を困難に する一因となっており, 結果的に共同意識や組織におけ る自分の役割を自覚する機会も限定的になっている。ま

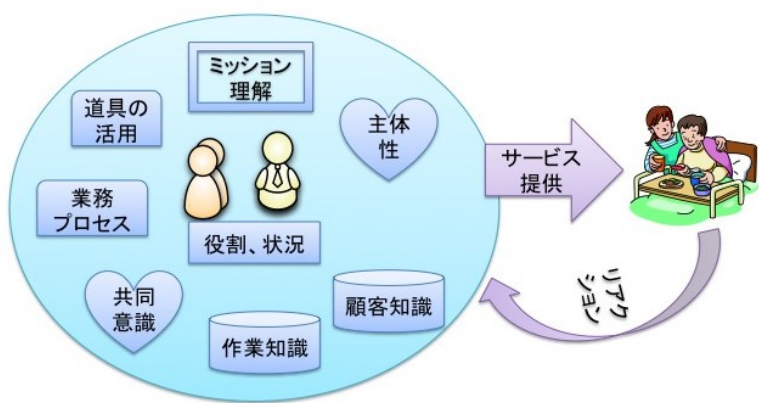

図 1 人起点サービス現場の従業員行動モデル[西村 2013b]

た，業務の実施に欠かせない道具（技術システム）の仕 様への反映や, 道具を現場へ埋め込むためのプロセス変 更も効率的に実施できない状況が発生している.

業務の形式化については，これまでに多くの研究が実 施されている，例えば，太田らは，看護業務の処理手順 を解析する手法を提案している[太田 2009]. また，西村 らは，オントロジー技術を用いた看護業務の形式化を行 い, 看護教育に役立てる取り組みをおこなっている[西村 2011]. 原らは，サービス現場における業務プロセスとそ こで使われるモノの挙動との相互作用を書き表す手法を 提案している[Hara 2008]. また, 業務プロセスの観測・ 分析についても多様な技術がこれまでに提案されている (例えば[黒田 2011，蔵田 2013]）。

一方，上述のアプローチの多くは，業務のある側面に フォーカスした手法となっている。 サービスの多様な側 面を表現するオントロジーを構築する試みも行われてい るが[住田 11], 業務プロセスに対し多様な見方がある中 で，対象のプロセスの観測・形式化により適した技術を 選択，活用するための方法論の開発が，現場の理解と改 善には不可欠である，製品設計分野では，設計手法の選 択法の提案が行われているが[野間口 2013], サービスの 改善・再設計を目的とした方法論はまだ十分に整備され ているとは言い難い。また，現場の従業員による運用を 想定した技術開発も，実際に現場に適用するにあたって の重要な課題となる。

\section{3. モノ・コトづくり支援のためのコトの DB 化に 向けた技術選択方法論の提案}

著者らは，現場の従業員の主観的な業務理解から客観 的な業務プロセスの観測結果まで, 多面的, かつ低コス トで収集・蓄積・モデル化する，コトの DB 化が本課題 解決に役立つと考える. 図 2 にコト DB 化の方法, 並び に同 DBを用いたモノ・コトづくり支援スキームを示す. コト DB 化は，業務観測や各種センサ等を用いたセンシ ング，業務システムのログの解析等，客観的なデータ収 集に加え, 各種業務記録の分析やワークショップを通じ た自己表現によって表出される, 個々の主観も情報とし て収集する，収集した情報をモデル化し，蓄積，分析す ることにより, 従業員による業務の振り返りや，業務シ ステム開発の前提情報として活用することが可能となる. 
コトのデータベース化

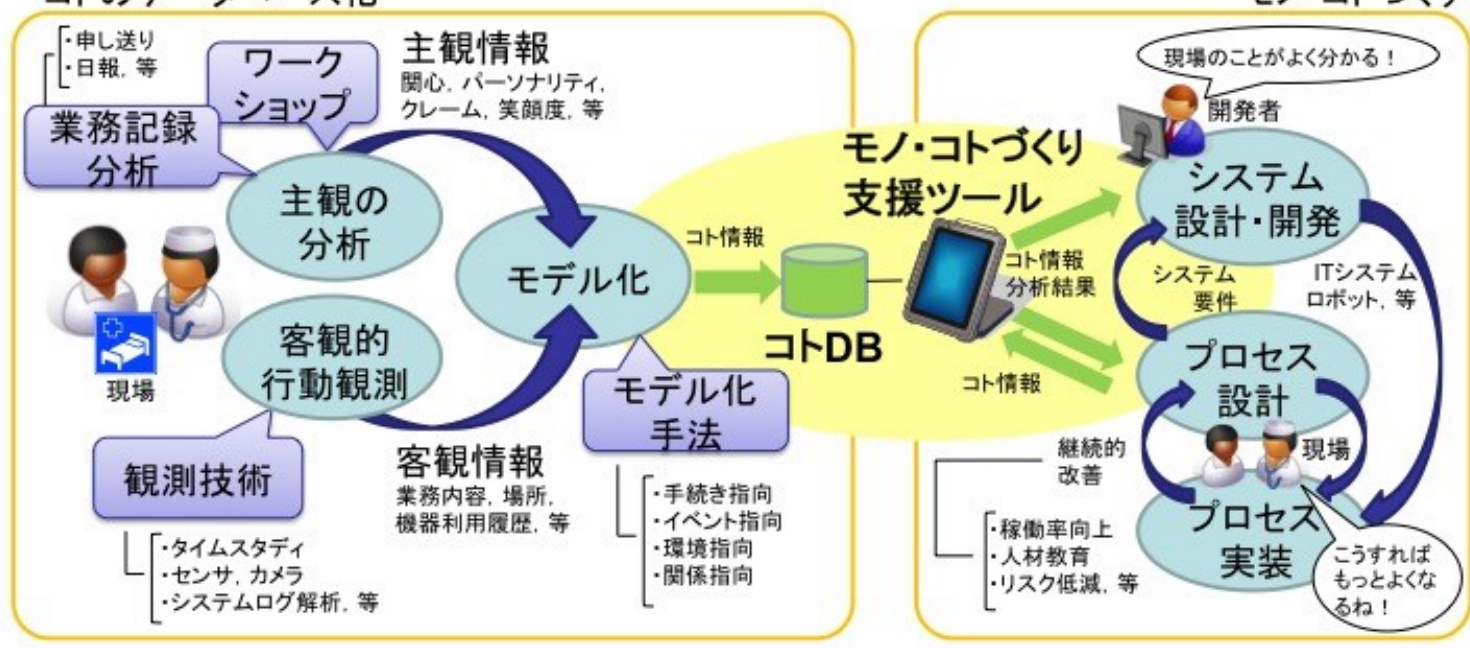

モノ・コトづくり

図 2 コト DB とモノ・コトづくり支援スキーム

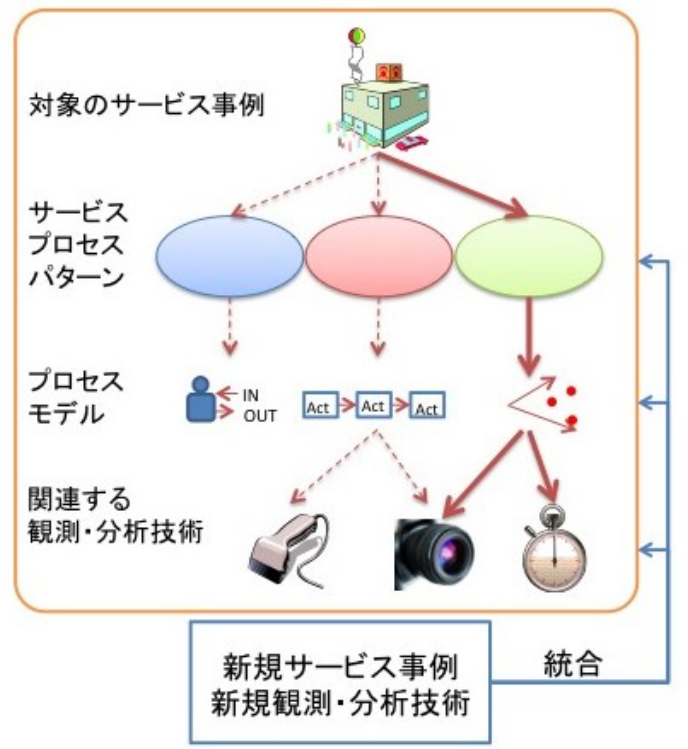

図 3 コト DB 化技術の選択方法論

一方，多様な業種業態の存在するサービス産業の分析に あたっては，個々の現場に対し適切な技術を用いた観 測・分析を行うことが必要となる。しかし, 現場毎に適 した技術を個別に選択するには，各種技術や現場の分析 に習熟した多数の専門家が必要となり，望ましくない.

そこで，本稿ではサービス現場の業務プロセスを類型 化し，同パターンに対応するモデルや観測・分析技術 (以 降，コト DB 化技術と呼ぶ）のマップを提示することに より，対象のサービスのコト DB 化に適切な技術の決定 を支援する方法論を提案する. 図 3 にその概要を示す. 本方法論は下記のステップで構成される.

（1）サービスプロセスパターンの選択

サービス現場におけるコトの DB 化にあたり，対象の サービスの業務プロセスの特徴を，現場観察や従業員等 現場関係者のヒアリング等を通じて確認し，後述する 4
種のサービスプロセスパターンに対応づける．本パター ンを用いる理由は，多数のサービス業種・業態を個別に 扱うのではなく，プロセスを特徴づける比較的少数のパ ターンに当てはめることで有効な技術選択・導入を効率 的に行えるためである.

（2）プロセスモデル，観測・分析技術の選択・適用 次に，同パターンに関連付けられた，サービスプロセ スを表現するためのコト DB 化技術を，同じく後述する 技術マップに基づき選択する．本過程では，サービスの 業務プロセスの特徴をより具体的に表現するためのプロ セスモデル，及び，同モデルを構成する要素を観測・分 析するための技術を選択する.

なお，これらのサービスプロセスパターンや関連付け られたモデルや観測・分析技術は固定的なものではない. 新しいサービスの事例や技術を取り込み，パターンやマ ップを継続的に更新するものとする.

以降，4節にて業務プロセスの類型を示し，5節にて， 類型結果と各種モデル，及び観測・分析技術を対応させ るコト DB 化技術マップとその適用事例を説明する.

\section{4. 業務プロセスの類型化}

業務プロセスの類型として，本稿では下記の 4 種のサ ービスプロセスパターンを提案する (表 1 参照).

\section{・手続き指向プロセス}

手続き指向プロセスは，逐次的な手順によって構成さ れるサービスプロセスパターンである。例えば，レスト ランにおける料理の提供プロセスは，注文 $\Rightarrow$ 調理 $\Rightarrow$ 配膳 という一連の手順として表現できる。このように，本パ ターンは，何度も実施されうる，標準的な一連の手順が 存在する場合に適している．既存の業務プロセスの分析 手法の多くは，本パターンを前提としている．本パター ンに基づく分析は，プロセスの効率化，あるいはシステ 
ムによる自働化を目的としていることが多い

適用対象サービスの例として，先述のレストランサー ビスの他，電話による技術サポート等が挙げられる。ま た，サービスを維持継続するためのサプライチェーンも 同パターンにより表現されることが多い.

\section{・イベント指向プロセス}

イベント指向プロセスは，何らかの外的な刺激，ある いは内的な動機づけによって引き起こされるプロセスパ ターンである．例えば，従業員が周囲の人間からの要望
を受け，実施する，あるいは，自発的に周囲の状況に気 づき，実施するような業務はこのプロセスとして表現さ れる.このプロセスパターンは，顧客や他の従業員に対 する柔軟な対応にその特長がある．前述の手続き指向プ ロセスと異なり，効率化や自働化が容易でなく，周囲の 状況や要求に対する適切な対応，あるいは従業員の業務 支援を目的として，本プロセスパターンに基づく分析が 実施される.

表 1 業務プロセスの類型化

\begin{tabular}{|c|c|c|c|}
\hline $\begin{array}{l}\text { サービス } \\
\text { プロセス } \\
\text { パターン }\end{array}$ & 概要 & 目的 & 対象プロセスの例 \\
\hline 手続き指向 & $\begin{array}{l}\text { 行動を手続き的に } \\
\text { 表現する }\end{array}$ & $\begin{array}{l}\text { 手順の可視化と } \\
\text { 合理化, 自動化 }\end{array}$ & 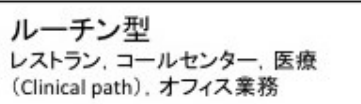 \\
\hline イベント指向 & $\begin{array}{l}\text { 何らかの内的·外的 } \\
\text { 刺激に基つく行動を } \\
\text { 表現する }\end{array}$ & $\begin{array}{l}\text { 行動の動機, 頻度, } \\
\text { 判断基準の可視化と } \\
\text { 行動支援 }\end{array}$ & 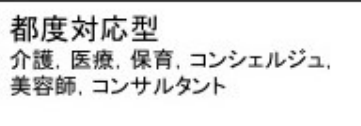 \\
\hline 環境指向 & $\begin{array}{l}\text { 行動をサービス環境 } \\
\text { 時空間上に } \\
\text { 紐づけて表現する }\end{array}$ & $\begin{array}{l}\text { 特定環境下における } \\
\text { 行動の可視化と } \\
\text { 効率化 }\end{array}$ & 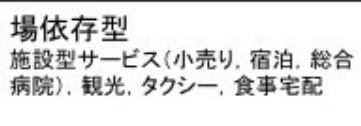 \\
\hline 関係指向 & $\begin{array}{l}\text { 行動を人の閏係· } \\
\text { やり取りと紐づけて } \\
\text { 表現する }\end{array}$ & $\begin{array}{l}\text { 関係·やり取りと } \\
\text { その影響·意図の } \\
\text { 可視化と合理化 }\end{array}$ & 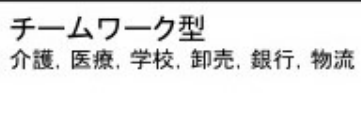 \\
\hline
\end{tabular}

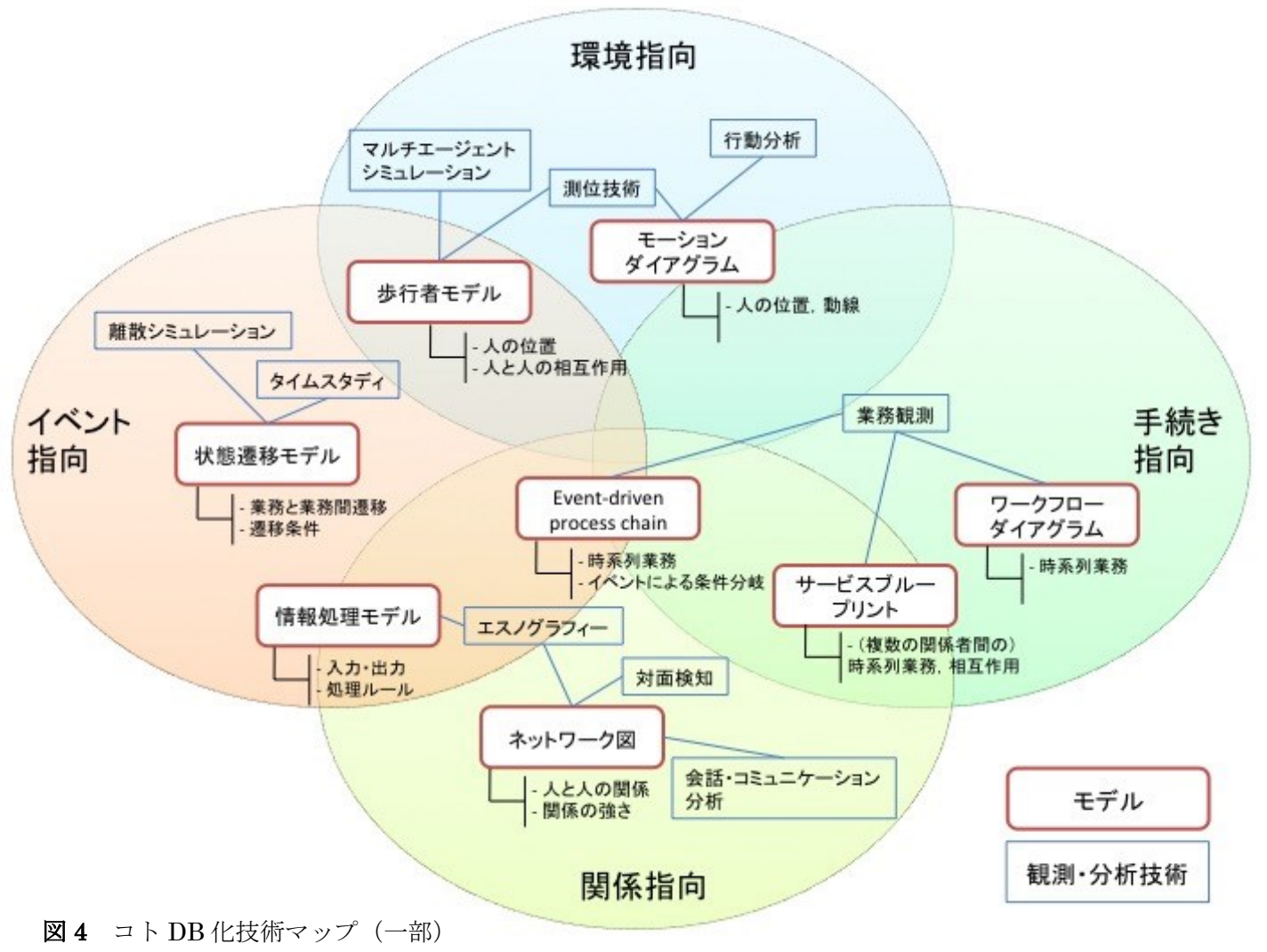

図 4 コト DB 化技術マップ（一部） 


\section{・環境指向プロセス}

環境指向プロセスは，サービス現場の場所や時間に紐 づけられて表現されるプロセスパターンである. 本プロ セスパターンでは，例えば建物の構造等，サービスの提 供環境が業務プロセスに与える影響や関係に焦点があて られ，業務上の無駄の削減や機会損失の低減等，プロセ スの効率化が改善の主たる目的となる．例えば，ホテル やレストラン, ショッピングセンター等, 店舗内の業務 動線の改善等が本プロセスパターンの代表的な課題とし て挙げられる。

\section{・関係指向プロセス}

関係指向プロセスは，顧客や従業員間の関係や協働に 焦点を当てたプロセスパターンである．従業員の専門性 が高く, 役割分担が明確なサービスでは，相互のコミュ ニケーションや情報共有が，満足度の高いサービスの実 現において非常に重要である。このようなサービスで重 視される, 従業員間のチームワークや利害関係者間の関 係が本プロセスパターンの主要な分析対象となる.また, 従業員間のコミュニケーション促進や業務配分の最適化 が本パターン適用の代表的な目的となる。

以上のサービスプロセスパターンはサービスにおけ る業務プロセスの特徴を浮き彫りにする視点を提供する ものである． 特定の業態を対象とする代わりに，業務の 特徴を類型化することで，多様な業態に対して有益な技 術を適用することが可能となる。また，本パターンは必 ずしも個々に独立したものではない。サービス現場の利 害関係者の関心も考慮し， 1 種類，ないし複数種のパタ ーンの観点から, コト DB 化を進めることが可能である.

\section{5. コト DB 化技術マップ}

次に，提案したサービスプロセスパターンと，同パタ ーンに対応するモデル，並びに観測・分析技術を関連付 けるコト DB 化技術マップの提案を行う. 図 4 に同マッ プの一部を示す。分析・改善対象のプロセスの特徴に適 したパターンを選択することにより，そのプロセスの分 析，設計に適したモデルや観測・分析技術をマップ上で 特定することができる，例えば，手続き指向プロセスを 表現するモデルとして, 逐次的な業務モデルであるワー クフローダイアグラム[van der Aalst 2004]をマップ上 で選択することができる．また，環境指向プロセスのモ デルとして，サービス現場の人の動きを表現するモーシ ヨンダイアグラムを用いることで，人の動きを変えるた めの業務環境の再設計を行うことが可能となる.

著者らは本サービスプロセスパターンに対応する個 別の支援技術開発も行っている．特に技術開発が比較的 少ない，イベント指向プロセス，関係指向プロセスに対 する支援技術の開発を行っている[渡辺 2014].

本稿では同技術マップに対応づけられる，具体的なサ
一ビスの分析・改善事例，さらに新規の事例に対し，同 技術マップを適用した事例を示す。

\section{1 手続き指向プロセスの関連事例}

手続き指向プロセスの設計の例として，医療の手続き を形式化した医療プロセス，あるいはクリニカルパスが 挙げられる。清水ら[Shimizu 2011]はソフトウェア，及び 情報システムの代表的なモデリング手法群である， Unified Modeling Language (UML) [OMG 2010]のアクテ ィビティ図を用いて, 医療プロセスの設計を行っている. 医療プロセスは迅速で安全な作業が求められるため，手 続き指向プロセスの考え方に合致した手続き的な記述に よるプロセス設計が有益，かつ適している。 また，原ら はエレベータの運用サービスを，エレベータシステムの 挙動も合わせてモデル化している[Hara 2008]. 前述のと おり，レストランにおける注文から料理提供までのプロ セスも，同様に手続き的な側面が強いプロセスの例とし て挙げられる。

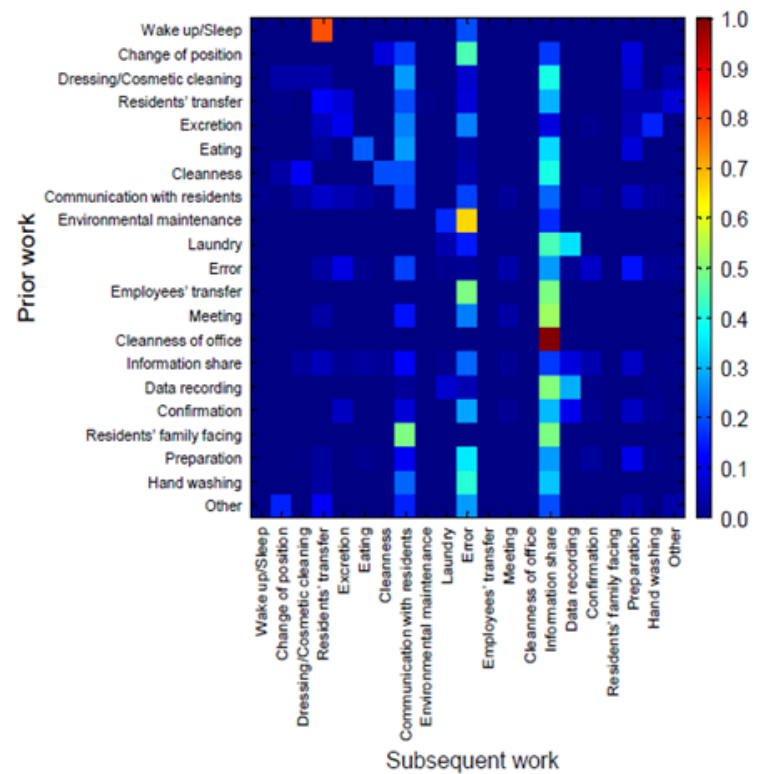

図 5 介護業務の状態遷移確率マップ[Miwa 2012]

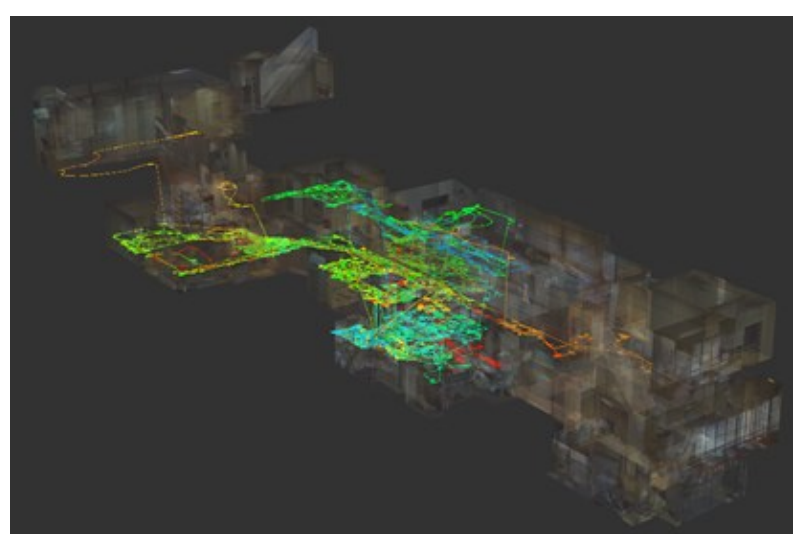

図 6 旅館における従業員の動線[持丸 2011] 


\section{2 イベント指向プロセスの関連事例}

イベント指向プロセスにおける, 状況に応じた対応を 可能とする, 従業員のスキーマの分析の例として, 従業 員に業務中の行動に合わせた VR 映像を見せながら回顧 インタビューを行う Cognitive Chrono-Ethnography (CCE) Lite という手法が，旅館の従業員業務の分析に応用され ている[Nakajima 2012].

一方，外部からの働きかけを主たるきっかけとする業 務が多いサービスの例として, 介護サービスが挙げられ る. 例えば介護施設では, 介護士の業務はしばしば入居 者や他のスタッフからの呼びかけによって中断される. このような業務プロセスの分析にあたり，三輪らは状態 遷移モデルを適用することで, 各業務の遷移パターンと その特徴の分析を行っている[Miwa 2012]. 本分析には, 状態として対応づけられる業務種類の列挙と, 実際の業 務状況の記録が不可欠である，そこで，三輪らは業務観 測や従業員インタビューに基づく業務のコード化と同コ ードを用いたタイムスタディを行っている．図５は観測 した結果を元に業務間の遷移確率をグラフ化したもので ある、このような可視化により，業務遷移とその影響や 原因の分析を行うことができ, 適切な対応（例えば従業 員の業務配分の再設計等）を行うことが可能となる. 他 サービスへの展開可能性として, 例えば保育園のサービ スにおいても, 子供の行動に反応寸る保育士の業務プロ セスにはイベント指向プロセスの特徵が見られ，上述の 手法の適用が期待できる.

なお，タイムスタディについては，観測やデータの集 計・分析に伴う負荷が大きいため, モバイルデバイスを 用いた記録, 集計方法の研究も行われており, サービス の質を計測するための基礎的な研究も進められている [三輪 2013].

\section{3 環境指向プロセスの関連事例}

レストランにおけるウェイターの業務は, 顧客の使う テーブルやキッチン等, 店舗内レイアウトに強く紐づけ られており, 従業員の移動量が業務の効率性と大きく関 連する. 本分析には, 従業員を時空間モデル上にマッピ ングすることが有効であると考えられる.

福原らは日本食レストランにおいて, 位置センサ等を 含む行動センシングデバイスを用いて従業員の移動や行 動の計測と分析を行い, 業務パターンの変更に伴う効果 の確認を実際に行っている[Fukuhara 2013]. 図 6 は, 同 様に, 旅館の 3 次元モデル上に従業員の動線をマッピン グしたものである．特に多数の従業員がいつどこで業務 を行っているかを把握するには，本事例にみられるよう に, 自動的に位置等の計測を行うセンサ技術の適用が有 効である. 同様に，位置情報を有効活用したサービスに は, 配送業やタクシー業等が例として挙げられる.

\section{4 関係指向プロセスの関連事例}

先述のとおり, 今日の医療サービスは, 医師, 看護師, 薬剤師，作業療法士等，異なる専門性を持つ従業員間の チームワークによって実現されている，そこで, 従業員 間の円滑な関係構築を目的として, 各種業務に関する従 業員間の共通認識を構築する試みが行われている．従業 員間で業務観の合意形成を行う手段として, 表現ワーク ショップ[藤満 2013]が試行されている．本手法では，業 務経験やその時に感じた思いをスケッチやエッセイによ って表現し，それを共有することで，個々の従業員の体 験や価值観を共有する。これにより, 従業員同士のコミ ユニケーションのきっかけを与え, 円滑な業務の実現に 寄与することができる．また，業務観を共有する手段と して, コンピュータ上で写真や描画機能を用いて協働表 現するツール”Zuzie”が用いられている[須永 2011]. 本 ツールは現状厳密な意味でのモデリングッールではない が，従業員の業務観を表現する，現場で運用可能なツー ルとして期待される.

一方，従業員間のコミュニケーションに着目し，その 観測とモデル化を通じて，チームワークの分析を行う試 みも行われている．例えば，チーム医療の分析事例の一 つとして, 救急救命分野における医療プロセス中の従業 員間のやり取りを，動線分析と会話分析によって分析す る試みが実施されている [依田 2012]. また，介護サー ビスにおける業務シフト間の申し送りやチーム内コミュ ニケーションを促進するための情報共有を支援するシス テムの設計, 開発も行われている. 介護・医療サービス では，バイタルや介助の記録を共有するだけでなく，家 族の要望の伝達や事務連絡を確実，かつスムースに実現 することがサービス品質向上のために必須である. そこ で，従業員主体による申し送り支援システムの開発と業 務変革が試みられている[福原 2013]. また, 音声つぶや きで協㗢を支援する技術も研究されている[内平 2012]. さらに，センサを用いたアプローチとしては，対面検出 と発話検知技術を導入し，ネットワーク図を用いてコミ ユニケーション状況を可視化する技術が開発されており, チームの活動レベルを計測する手段として注目されてい る[Ara 2011].

\section{5 新規事例に対する提案手法の適用結果}

最後に，本提案手法を新規事例に適用した結果を示す. 本稿で取り上げる事例は，医師らによって実践されて いる，高齢者を対象とした健康支援サービスである．取 り組みの特徴は医師による診察, 栄養学に基づく食事の 指導，スポーツクラブにおける運動指導，アロマを活用 したメンタルケアを体系的に高齢利用者に提供し, 心身 ともに改善する点である。また，スタッフ自身がやりが いを感じ, 利用者と一体となってビジョンの実現に邁進 している点も特長である.

本サービスの従業員は全 16 人で,「クリニック」「栄 
表 2 サービスプロセスパターンとコト DB 化技術の対応関係

\begin{tabular}{|c|c|c|c|c|c|c|c|}
\hline \multirow{2}{*}{$\begin{array}{l}\text { サービス } \\
\text { プロセス } \\
\text { パターン } \\
\text { モデル }\end{array}$} & \multicolumn{2}{|c|}{ 手続き指向 } & \multicolumn{2}{|c|}{ イベント指向 } & \multirow{2}{*}{$\begin{array}{l}\text { 環境指向 } \\
\text { 時空間モデル } \\
\text { 施設の3次元 } \\
\text { モデル }\end{array}$} & \multicolumn{2}{|c|}{ 関係指向 } \\
\hline & $\begin{array}{l}\text { アクティビティ } \\
\text { 図 }\end{array}$ & $\begin{array}{l}\text { 拡張サービス } \\
\text { ブルーブリント }\end{array}$ & $\begin{array}{l}\text { 状態遷移 } \\
\text { モテル }\end{array}$ & スキーマ & & $\begin{array}{l}\text { 業務に関する } \\
\text { 共通認諳.表現 }\end{array}$ & ネットワーク图 \\
\hline $\begin{array}{l}\text { モデル } \\
\text { 要素 }\end{array}$ & $\begin{array}{l}\text { 行為. 分岐 } \\
\text { 条件 }\end{array}$ & $\begin{array}{l}\text { 人, モノ, 行為. } \\
\text { 攀動, 相互作 } \\
\text { 用. 分岐条件 }\end{array}$ & $\begin{array}{l}\text { 従業員の種類, } \\
\text { 業務(コ一ド化). } \\
\text { 業務間の遷移 }\end{array}$ & $\begin{array}{l}\text { 人, 行動, 意图. } \\
\text { 臬因 }\end{array}$ & $\begin{array}{l}\text { 従業員, 位置. } \\
\text { 時刻. 施設 } \\
\text { 環境 }\end{array}$ & $\begin{array}{l}\text { 䢨業員. 行為. } \\
\text { 思い, 従業員 } \\
\text { 間の関係 }\end{array}$ & $\begin{array}{l}\text { 人. コミュニ } \\
\text { ケーション(回 } \\
\text { 数. 対象) }\end{array}$ \\
\hline $\begin{array}{l}\text { 䚒測· } \\
\text { 分析技術 }\end{array}$ & 業務観測 & 莱務観測 & $\begin{array}{l}\text { タイムスタディ. } \\
\text { 業務分類・ } \\
\text { コード手法 }\end{array}$ & $\begin{array}{l}\text { CCE Lite(回顔 } \\
\text { インタビュー. } \\
\text { 位置センサ.VR } \\
\text { 技術) }\end{array}$ & $\begin{array}{l}\text { 位置, 高度, 加 } \\
\text { 速度等のセン } \\
\text { サ群, 3D罧境 } \\
\text { 構築技術 }\end{array}$ & $\begin{array}{l}\text { 協㑬表現ツー } \\
\text { ル. ワーク } \\
\text { ショップ }\end{array}$ & $\begin{array}{l}\text { 赤外線センサ, } \\
\text { 発話センサ }\end{array}$ \\
\hline 事例 & $\begin{array}{l}\text { 看護手順の } \\
\text { 分析 }\end{array}$ & $\begin{array}{l}\text { エレベータシス } \\
\text { テム, 運用 } \\
\text { 莱務の設計 }\end{array}$ & $\begin{array}{l}\text { 介護業務の } \\
\text { 分析 }\end{array}$ & $\begin{array}{l}\text { 旅馆における } \\
\text { 従菜員の行動 } \\
\text { 分析 }\end{array}$ & $\begin{array}{l}\text { レストランに } \\
\text { おける従業員 } \\
\text { の動線分析 }\end{array}$ & $\begin{array}{l}\text { 看護業務にお } \\
\text { ける共通認識 } \\
\text { 構築 }\end{array}$ & $\begin{array}{l}\text { オフィス業務 } \\
\text { 分析 }\end{array}$ \\
\hline
\end{tabular}

養」「運動」「アロマ」および「主任」の 5 つのグループ が構成されている。本論文の提案手法に従って，まず, 現場に対するサービスプロセスパターンの適用を行った， 現場の作業内容をヒアリングし，実際に作業の様子を観 察したところ, チーム内の関係・やりとりが重要となる 関係指向のプロセスに位置づけられることが分かった. また，朝礼等の対面での情報伝達，およびスマートフォ ンによるコミュニケーションが行われているが，利用者 情報やイベント情報が分散し，理解に手間がかかるとい う問題があった。

このような関係指向のプロセスにおいて，情報共有の 状況をネットワークとして分析し，かつ支援する技術と して，提案した技術マップから，職員間の情報共有を支 援する申し送りシステム DANCE[福原 2013]が有効であ ることが分かった．そこで既に利用されているスマート フォンの利用履歴に加え, 同端末にインストールした DANCE によるコミュニケーション，及び，その内容の 分析を通じた, 従業員間のやり取りや活動の把握を行う こととなった。本分析を通じて，同サービスの活動がど のように利用者の心身改善に寄与しているか検討する. これらの検討を進めることで，利用者やイベント等の情 報共有のための構造化情報の導入等, DANCE システム の改善方針も決定できる見込みである。

\section{6. 考察と今後の課題}

\section{1 技術選択方法論について}

本稿では，提案したサービスプロセスパターン，及び コト DB 化技術マップに合わせ，複数の既存のサービス プロセスの分析・改善事例を示した. 表 2 に各事例，モ デル，観測・分析技術を整理する。このようにサービス プロセスパターンにコト DB 化技術の関連付けを行うこ とにより，新規の事例に対し共通の技術をあてはめるこ とが可能になると考えられる。また，同プロセスパター ン，技術マップを用いた技術選択方法論を健康支援サー
ビスに適用し，具体的な観測・分析技術の選択を行うこ とができることを示した．現状のパターンやマップは今 後本稿で言及した以外のサービス業種や今後次々登場し てくると想定される新しいサービスや各種設計手法を取 り込みつつ，継続的に更新していくことが必要である. このためには，研究者や各種サービス提供者を交えたコ ミュニティによるメンテナンス活動を行っていくことが 考えられる. 著者らは, 今後, 上述のコト DB 化技術マ ップのメンテナンスを支援するシステムの研究を進めて いく予定である.

また，本稿で提案したアプローチは，サービスプロセ スパターンの選択にあたって，抽象的な条件しか示して おらず，利用者に選択の余地を残している。本稿では， 医療サービスにおける設計事例として，業務中のミスを 減らすことを目的としたクリニカルパスのように，手続 き指向プロセスとして業務プロセスを分析した例と，医 療チームの総合的なパフォーマンスを改善する目的から, 従業員間のやり取りに着目した関係指向プロセスとして 分析を行った例の両方を紹介した。このことは，業務プ ロセスの持つ多面性を示しており，柔軟に多様なパター ンのあてはめを行うことによって，これまでにないプロ セスの革新や価值の創出を実現できる可能性を示唆して いる。一方，各種技術やモデルの適用には，例えばコス 卜や観測の要求精度等，適用の前提条件が存在する。ま た, どういう評価基準に基づいてサービスを評価するか, 等，分析目的に即した技術の選択も重要なポイントとな る. 以上の適用条件の整理については，今後の検討課題 である。

\section{2 各種コト DB 化技術について}

コト DB 化技術として，従業員が簡便に用いることの できるシステムを実現するにあたっては，今後様々な技 術との融合を行うことが有効と考えられる，例えば，各 種センシング技術や機器操作情報との連携, 音声や写真 等, 入力メディアの多様化, 初期知識の構築によるシス 
テムのホットスタート等が具体的な課題となる。また, データの分析手法として, 入力文書の形態素解析, 頻度 分析, 類義語, 写真の文字や顔の認識, 音声の認識, 日々 の申し送り情報から利用者や業務の知識抽出する技術も 有効であろう。さらに，新しいモデリング手法の開発・ 導入も必要と考えられる.

加えて, 業務プロセスの分析結果を, サービス現場の 従業員の役割・業務分担や組織の再編成, 新規システム 導入等, 個々の現場の業務プロセスや組織のデザインに 適切に反映できるよう, 現場で運用可能な設計支援シス テムの実現に向けた研究開発を行っていく必要がある.

\section{3 コト DB による情報共有の発展可能性について}

コトの DB 化が進むことにより，一施設・店舗の業務 プロセスの特徵を他施設・店舗と比較する, あるいは成 功事例を参照することが可能となる. このような情報共 有は, 直接競合関係にない同業他社や異業種も巻き込ん だ総合的なサービス業の生産性向上に寄与するものと期 待される. 反面, 情報の公開範囲やプライバシーの担保 等, 困難な課題も存在する. これらについても今後の課 題である。

また，業務システムのベンダーが，コト DB を通じて 現場固有のコトをより詳細に把握できるようにすること で, どのような機器やその機能がどの程度効果があるか 分かり, 適切な要求仕様を策定できるようになることが 期待される.このように, サービス現場の行動変容, 業 務プロセス改善と共に, 現場を詳細に把握できないシス テム開発者や他の関連現場の支援に繋げることも今後の 課題である.

\section{4 今後のチャレンジに向けた課題}

以上の考察にも見られるとおり, 従業員が主体的にサ 一ビス現場の情報を活用するための各種情報入力支援, 並びに画像・音声処理やベイズ推定等の大規模データ分 析技術を含む状況認識技術, さらには, 膨大なコト情報 を取り扱うための情報推薦, 高速 DB 検索技術等, 各種 人工知能技術がコト $\mathrm{DB}$ を用いた人起点のサービスの課 題解決の鍵となる. 特に, サービスの正確な観測と改善 のためには, システムだけでなく従業員のモチベーショ ンを高め, 協働してサービスを改善・設計する方法論と 技術が両輪で必要となる.

このために, 今後, 以下のようなロードマップでプロ ジェクトを推進する予定である.

・ 1 年目 コト DB の仕様検討

コト DB のデータ構造，ならびにデータ格納方法に関 する仕様の検討を進めている.

・ 2 年目 コト DB 基盤整備

1 年目の検討結果に基づき，コト $\mathrm{DB}$ 仕様に基づくデ
一タ基盤を整備し，データを収集，利活用する技術を実 装したアプリケーションを複数用意する.

・ 3 年目 設計方法論とコト DB 活用技術の確立

コト DB を用いた従業員主導のサービス設計の方法論 とそのためのコト DB の情報活用技術を確立する.

・ 4 年目 介護, 看護にて数例の適用を実現 開発した技術，及び方法論を介護・看護分野で複数の 適用例を構築する。

・ 5 年目 各種サービス現場用技術パッケージの構築 介護・看護分野以外にも多様なサービス現場向けに技 術のパッケージ化を行う。

\section{7. まとめ}

本稿では，人起点のサービスの業務の形式化と分析を 目的とし，業務プロセスの情報を蓄積・共有するコト $\mathrm{DB}$, 並びに，コト DB の情報を用いて効率的にサービス現場 におけるモノ・コトづくりを支援する方法を提案した. さらに，具体的なアプローチとして，サービスの業務プ ロセスの特徵を分類する, 4 つのサービスプロセスパタ ーン：手続き指向プロセス, イベント指向プロセス, 環 境指向プロセス，関係指向プロセスの提案を行い，同パ ターンに対応するコト DB 化技術マップを提示した。ま た，複数のサービス分析・改善事例を本マップの枠組み に当てはめ, その有効性について論ずると共に, コト DB 化を中核としたサービス現場の分析・改善の今後の発展 の方向性について言及した。

近年，各企業においても，各種センサやスマートフォ ンだけでなく，業務改善を目的としたワークショップも 含め，多様な手法・技術の導入意欲が活発であり，先述 の事例に見られるようにコトづくりを実行するためのシ 一ズを提供可能な企業や大学も相当数存在している．著 者らが提案した近未来チャレンジの枠組みにおいて，今 後 5 年でサービス現場のコトの観測・形式化技術や分 析・俯瞰・共有技術の開発と導入が大きく進むと予想さ れる. モノづくり一辺倒の閉塞感と反省から，コトづく りの重要性が産業界において強く認識されていることか ら，今後，コト DB 化技術の開発，普及により，各種サ ービス業はもちろん, サービス化を志向する製造業も含 めた産業全体の生産性向上, 並びに生活者・従業員の生 活の質や業務環境の改善が見込まれる。また, コト DB のサービス現場の実データを基に，人工知能技術の実用 化も更に進展するものと考えられる. 今後, 更にこの分 野に多くの研究者や企業が参画し, 発展していくことを 期待したい. 


\section{謝辞}

本研究の一部はJSPS 科研費 25730190 の助成を受けた ものです.

\section{$\diamond$ 参考文献 $\diamond$}

[Ara 2011] Ara, K., Akitomi, T., Sato, N., Tsuji, S., Hayakawa, M., Wakisaka, Y., Ohkubo, N., Otsuka, R., Beniyama, F., Moriwaki, N. and Yano. K.: Healthcare of an organization: using wearable sensors and feedback system for energizing workers, In Proceedings of the 16th Asia and South Pacific Design Automation Conference, pp. 567-572 (2011)

[有馬 2013] 有馬 淳, 千葉 広隆, 中川 肇: フィールド・イノ ベーション: 現場参加型の業務改革, 人工知能学会誌, Vol. 28, No. 6, pp. 880-885 (2013)

[藤満 2013] 藤満 幸子, 山口 真由美, 原田 由美子, 椛島 久美 子, 宮之下 さとみ, 南里 美貴, 百武 朋美, 山田 クリス孝 介, 須永 剛司, 小早川真衣子, 新野 佑樹,渡辺 健太郎, 西村 拓一: 医美工連携による看護情報システムの開発を 目指したデザイン・プロジェクト，医療情報学連合大会論 文集，Vol. 33, pp. 908-911 (2013)

[Fukuhara 2013] Fukuhara, T., Tenmoku, R., Okuma, T., Takehara, M., and Kurata, T.: Measuring and evaluating real service operations with human-behavior sensing: a case study in a Japanese cuisine restaurant, In Proceedings of the 19th Korea-Japan Workshop on Frontiers of Computer Vision, pp. 113-116 (2013)

[福原 2013] 福原 知宏, 中島 正人, 三輪 洋靖, 濱崎 雅弘, 西 村 拓一: 情報推薦を用いた高齢者介護施設向け申し送り 業務支援システム, 人工知能学会論文誌, Vol.28, No.6, pp. 468-479 (2013)

[Hara 2008] Hara, T., Arai T., and Shimomura, Y.: Integrated Representation of Function, Service Activity, and Product Behavior for Service Development, In Proceedings of the 13th Design for Manufacturing and the Life Cycle Conference DFMLC2008 -, (2008)

[蔵田 2013] 蔵田 武志, 天目 隆平: 従業員行動計測によるサ ービスプロセスリエンジニアリング, 人工知能学会誌, Vol.28, No.2, pp.238-244 (2013)

[黒田 2011] 黒田 知宏, 野間 春生, 内藤 知佐子, 山中 寛恵, 竹村 匡正, 任 和子, 吉原 博幸 : 発生源がバイタル計測・ 記録するセンサーネットワークシステムの試作，第 15 回 日本医療情報学会春期学術大会, 第 15 回日本医療情報学 会春期学術大会 (2011)

[Miwa 2012] Miwa, H., Fukuhara, T., and Nishimura T.: Service Process Visualization in Nursing Care Service Using State Transition Model, In Proceedings of the 4th International Conference on Applied Human Factors and Ergonomics (2012)

[三輪 2013] 三輪 洋靖, 渡辺 健太郎, 福原 知宏, 西村 拓一: 従業員の行動推定を用いたタイムスタディ支援システム の開発, 生活生命支援医療福祉工学系学会連合大会講演 論文集, pp. OS2-2-4 (2013)

[持丸 2011] 持丸 正明: 平成 23 年度 産総研サービス工学シン ポジウム サービス工学基盤技術の導入と普及一の戦略: 本格研究による人起点のサービス工学基盤技術, https://unit.aist.go.jp/cfsr/2011/symposium0906/Mochi maru20110906.pdf (2011)

[Nakajima 2012] Nakajima, M., Yamada, K. C., and Kitajima, M.: Cognitive Chrono-Ethnography Lite,
Work: A Journal of Prevention, Assessment and Rehabilitation, Vol. 41, No. 1, pp. 617-622 (2012)

[西村 2011] 西村 悟史, 來村 徳信, 笹嶋 宗彦, ウイリアムソ ン彰子, 木下 智香子, 服部 兼敏, 溝口 理一郎：看護手 順書問題の CHARMing な解決法, 医療情報学連合大会論 文集，Vol. 31, pp. 510-513 (2011)

[西村 2013a] 西村 拓一，渡辺 健太郎，本村 陽一：特集「介 護・医療システムの現場参加型開発」にあたって, 人工知 能学会誌，Vol. 28, No. 6, p. 879 (2013)

[西村 2013b] 西村 拓一, 渡辺 健太郎, 福原 知宏, 三輪 洋靖, 本村 陽一：ヘルスケアサービスにおけるユーザ主体のモ ノ・コトのデザイン, 第 1 回サービス学会国内大会 (2013)

[野間口 2013] 野間口 大, Askhoj, A., Madsen, K. F., 藤田 喜 久雄：製品系列設計のための設計法選択の支援に関する 研究，日本機械学会論文集 C 編, Vol. 79, No. 799, pp. 866-879 (2013)

[OMG 2010] Object Management Group (OMG): OMG Unified Modeling Language (OMG UML), Infrastructure Version 2.3 (2010)

[太田 2009] 太田順, 承敏鋼, 武部 芳弘, 金井 Pak 雅子, 桑原 教彰, 小作 浩美, 小暮 潔: 病院での看護業務処理手 順の解析と支援, 人工知能学会身体知研究会第 5 回研究会 予稿集, pp. 33-36 (2009)

[Shimizu 2011] Shimizu, S., Tomizawa, R, Iwasa, M., Kasahara, S., Suzuki, T., Wako, F., Kanaya, I., Kawasaki, K., Ishii, A., Yamada K., and Ohno, Y.: Nursing Business Modeling with UML: From Time and Motion Study to Business Modeling, Modern Approaches To Quality Control, Chapter 22, InTech, pp. 405-414 (2011)

[住田 2011] 住田 光平, 來村 徳信, 笹嶋 宗彦, 溝口 理一郎： サービスオントロジーの試作とその基本的考え，日本機 械学会第 21 回設計工学・システム部門講演会論文集 (2011)

[須永 2011] 須永 剛司，小早川 真衣子，高見 知里 : ことのデ ザインー情報デザインによる市民芸術創出プラットフォ 一ムの構築から見出したこと, 特集「参加型表現ワークシ ヨップ」, 人工知能学会誌, Vol. 26, No. 5, pp. 440-448 (2011)

[内平 2012] 内平 直志, 鳥居 健太郎, 知野 哲朗, 平林 裕治, 平石 邦彦，杉原 太郎：看護・介護サービスのための時 空間を越えたコラボレーション支援, 人間生活工学, Vol. 13, No. 1, pp. 34-37 (2012)

[van der Aalst 2004] van der Aalst, W., and van Hee, K. Workflow Management: Models, Methods, and Systems, The MIT Press (2004)

[Watanabe 2013] Watanabe, K., and Nishimura, T.: A unified approach for systematic and participatory design, In Proceedings of the 19th International Conference on Engineering Design (ICED2013) (2013)

[渡辺 2014] 渡辺 健太郎, 西村 拓一, 本村 陽一：モノ・コト づくり支援システム「UPAD toolkit」の開発，第 28 回人 工知能学会全国大会予稿集, No. 1L4-NFC-05a-5 (2014)

[依田 2012] 依田 育士, 大西 正輝, 川島 理恵, 黒嶋 智美, 織 田 順, 三島 史朗, 太田 祥一, 行岡 哲男: 救命救急医療 におけるチーム医療行為解析のための動線と会話の同時 解析システム, 映像情報メディア学会誌, Vol. 66, No. 5, pp. 158-166 (2012)

〔担当委員 : 阿部 明典〕

2013 年 11 月 30 日 受理 


\section{著 者 紹 介}

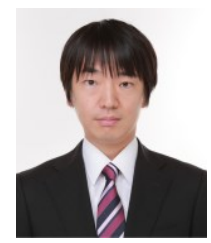

\section{渡辺 健太郎}

産業技術総合研究所サービス工学研究セン ター所属. 工学博士. 2005 年東京大学大学 院工学系研究科精密機械工学専攻修士課程 修了. 民間企業勤務を経て, 2012 年首都大 学東京大学院システムデザイン研究科博士 後期課程修了の後, 現職. 専門は設計工学,

サービス工学. サービス設計方法論, 並びに支援技術の研究に 従事.

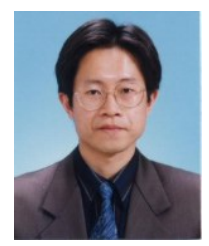

西村 拓一（正会員）

1992 年東京大学工学系大学院課程修了. 同 年 NKK(株)入社. 2001 年産業技術総合研究 所サイバーアシスト研究センター, 同情報 技術研究部門実世界指向インタラクション グループ長, NEC 出向などを経て 2011 年 より同サービス工学研究センターサービス プロセスモデリング研究チーム長. 博士(工学). 介護・看護サ 一ビス, コミュニティ支援, インタラクション技術, 時系列デ 一夕検索・認識に興味を持つ。

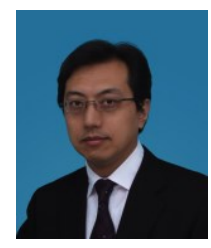

本村 陽一（正会員）

1993 年電子技術総合研究所入所, 2001 年産 業技術総合研究所情報処理研究部門主任研 究員, 2003 年同研究所デジタルヒューマン 研究センター主任研究員. 2008 年同研究所 サービス工学研究センター大規模データモ デリング研究チーム長. 2010 年〜統計数理 研究所客員教授, 東京工業大学連携准教授兼務. 2011 年 同研 究所サービス工学研究センター副研究センター長. 博士 (工学). 知能情報学, 機械学習, サービス工学などの研究に従事. 人工 知能学会研究奨励賞, 全国大会優秀賞, ドコモモバイルサイエ ンス賞, IPA 未踏ソフトウェアスーパークリエーターなど受賞.

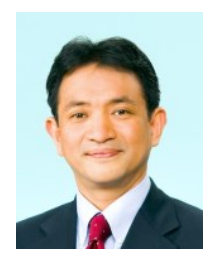

\section{持丸 正明}

産業技術総合研究所デジタルヒューマン研 究センター, 及びサービス工学研究センタ 一 センター長. 慶應義塾大学理工学部機 械工学科卒業, 同大学大学院修士, 博士課 程生体医工学専攻修了. 工業技術院生命工 学工業技術研究所を経て現職. 博士 (工学).

専門は人間工学, バイオメカニクス. IEEE Computer Society, SAE, 日本人間工学会等の会員. 2002 年, 新技術開発財団・市村学術 賞受賞. 